\title{
Legal Aspects of PT. Gojek Indonesia in the Partnership Agreement Dealing with the Public Transport Standards
}

\author{
Suhartoyo Suhartoyo ${ }^{1,2^{*}}$,Sonhaji Sonhaji ${ }^{1}$, Muhamad Azhar ${ }^{1}$, dan Putut Suharso ${ }^{3}$ \\ ${ }^{1}$ Faculty of Law, Diponegoro University, Prof. H. Soedarto SH street, Semarang 50275 Indonesia \\ ${ }^{2}$ Administrative Law Study Center, Diponegoro University, Prof. H. Soedarto SH street, Semarang \\ 50275 Indonesia \\ ${ }^{3}$ Department of Library and Information Science, Diponegoro University, Prof. H. Soedarto SH street, \\ Semarang 50275 Indonesia
}

\begin{abstract}
This study aims to explain the accountability of PT. Gojek Indonesia through a partnership agreement with Driver Gojek Online, in order to fulfill transportation usage standards. The research method used in this study is legal research that uses an empirical approach, using quantitative data. The results show that PT. Gojek Indonesia can be held accountable and liable related to legal relations through a partnership agreement with online Gojek drivers. Accountability and accountability are based on the legal relationship between the two parties in order to share responsiveness if there is a risk of accidents or damage to the environment caused by online ojek activities. The share responsiveness has a positive impact on maintaining vehicle facilitation indirectly, through maintenance of motorized vehicles on a regular basis and through the replacement of vehicles when the vehicle has exceeded the age of 10 years borne by PT. Gojek Indonesia Driver.
\end{abstract}

\section{Introduction}

Humans in interacting activities must always move and move from one place to another. Activities of moving and moving this place also become an integral part of everyday human life so that humans use transportation as a means to make it easier to achieve the goals of their activities. Along with the times and technology, transportation tools are increasingly developing and providing convenience for humans [1]. Distance and time are no longer considered as an obstacle for humans to go or to a place so that the means of transportation also get their own place in the dynamics of human life. The rapid development of transportation facilities and infrastructure plays an important role as a regional liaison to support, encourage and mobilize development. Without the existence of transportation as a supporting means it cannot be expected to achieve satisfactory results in a country's economic development efforts.

\footnotetext{
*Corresponding author: suhartoyo@undip.ac.id
} 
One that is quite prominent in Indonesia is the presence of PT. Go-Jek Indonesia, which produces Gojek (online-based transportation) provides many solutions to the needs of the community. Inevitably, the solution provided is a lucrative business land. At present, in Indonesia, especially in big cities like Jakarta, the increasingly widespread use of application technology by the public to meet their needs[2], and more and more entrepreneurs are using application technology as a medium to sell services and goods that they offer. The use of online transportation because it is supported by smartphone usage in Indonesia in 2014 only reached 52.2 million users. The number crawls up as in Figure 1 below:

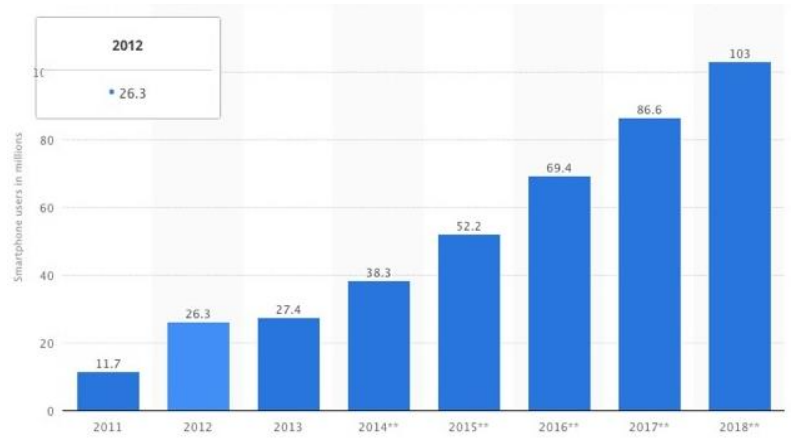

Source: http://strategihukum.net/peran-pemerintah-dalam-mengatur-bisnis-jasa-berbasis-teknologiaplikasi

Fig. 1. Use of a smartphone for online transportation in Indonesia

Gojek is one of the short-distance transportation facilities which is now popular among the public amid the emergence of modern transportation equipment such as taxis, buses, public transportation, commuter line electric trains. According to the Big Indonesian Dictionary ojek in its sense is a bicycle or motorbike that is objectified (added) by riding a passenger or tenant to obtain (additional) income. Along with the development of the time, the position of ojek cannot be underestimated as one of the livelihoods. This is marked by the emergence of Go-Jek, a service provider company that brings together motorcyclists, who own their own motorized vehicles to be used as an ojek to the online-based community[3].

The growth of the online-based motorcycle taxi business was followed by increasing public interest. This is indicated by the number of downloaders of the Go-Jek application that has reached 10 (million) million downloaders. Crowded news that raised the story of online motorbike drivers from an economic standpoint made people flock to become drivers. Go-Jek has now become an extraordinary phenomenon, especially for people in big cities who feel the impact of Go-Jek because it is considered as a solution to congestion and poor public transportation available[4]. Go-Jek is judged to be faster, more affordable and online-based, making it more efficient and easy to order. 


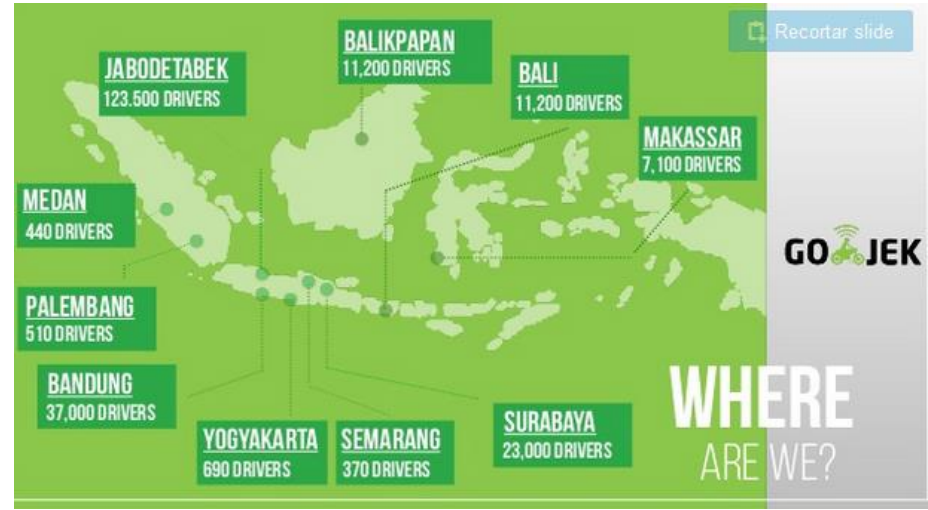

Source : https://pt.slideshare.net/AlamandaShantikaSant/gojek-happiness-story-62926678/9

Fig. 2. Driver Data until 2015

Go-Jek is an innovation of conventional motorcycle taxi based on online applications managed by PT. Go-Jek Indonesia, whose presence has now spread to cities that are strategic, such as the city of Semarang. The presence of Go-Jek in Semarang is certainly a breath of fresh air for the people, especially job seekers. Semarang, which has long been known as a student city, has also experienced development as a province that has a growing economic activity and the flow of people and goods moving rapidly and continues to increase, this is coupled with a considerable population density. So it is not surprising that modern transportation facilities such as Go-Jek since its first appearance in Semarang have now grown rapidly.

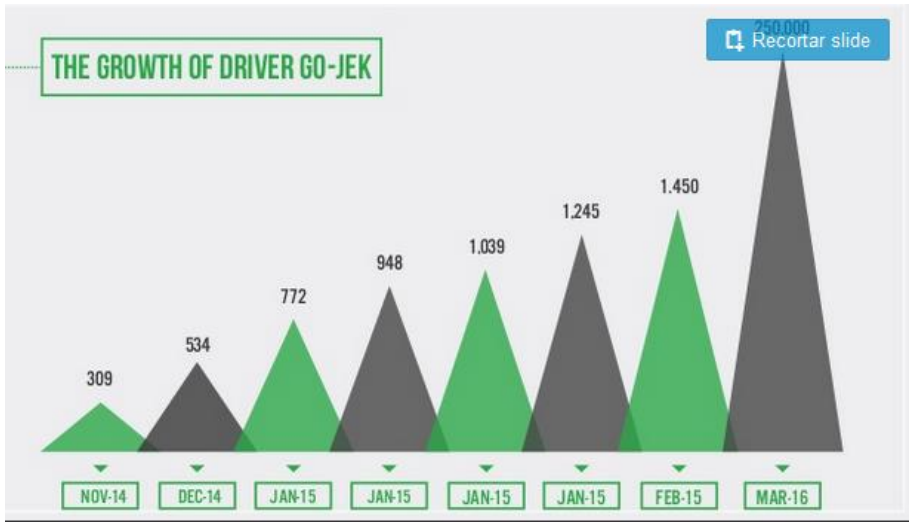

Source : https://pt.slideshare.net/AlamandaShantikaSant/gojek-happiness-story-62926678/9

Fig. 3. The Growth og The Driver Gojek

There is an interesting phenomenon that occurs in the community, in the general public considers that the Go-Jek drivers are employees of the application service provider company so that between them there is an employment relationship. The reasons vary from the obligation of the Go-Jek driver to guarantee securities such as diplomas or other securities at the beginning of registering to the issue of wages and insurance given to motorcycle drivers. In practice, it turns out that the Go-Jek partner recruitment system or commonly referred to as the Go-Jek driver uses a partnership system. This partnership partnership is based on an agreement made with the agreement of both parties. The 
agreement was made with a balanced position between the parties. Considering this, it is impossible for legal protection to be obtained by both parties based on employment and employment agreements according to Law No. 13 of 2013 concerning Manpower. The prevailing regulations in Indonesia must be the protection of all Indonesian citizens with various professions through laws and regulations in various sectors, ranging from agriculture, marine fisheries, industry, information technology and various other sectors[5], [6].

There is a difference between the employment agreement and the partnership agreement, however it is necessary to see further the practices carried out because of the partnership agreement carried out by PT. Go-Jek with Go-Jek drivers has similarities with work agreements. The employment agreement is said to be an agreement between the worker/laborer and the employer or employer which contains the terms of employment, rights and obligations of the parties [7].

This needs to be seen indeed not all elements in the partnership agreement are the same as the employment agreement. Some things can be likened to those made by the parties, obligations and rights of the parties and working conditions, even though for the element of wages it needs to be ensured further. Wages are workers' rights that are received and stated in the form of money in return from employers or employers to workers/laborers who are determined and paid according to a work agreement, agreement, or legislation, including benefits for workers/laborers and their families for a job and/or services that have been or will be carried out.

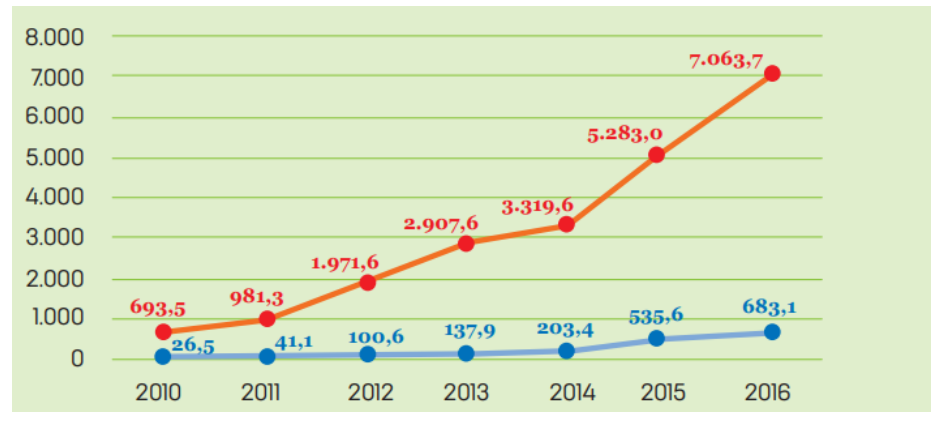

Source: https://teknorus.com/grafik-perkembangan-bisnis-gojek-di-indonesia-ke-depan/

Fig. 4. Volume of the E-Money Transaction

Apart from the above problems, partnership practices carried out with relationships that tend to be subordinate, such as those in the work agreement even though it is juridical, should be coordinative. Before entering into a partnership agreement unilaterally stipulated by PT Go-Jek or made in the form of a standard agreement whose clauses have been standardized in the agreement. This has become one of the problems that need to be explored starting with the definition of legal/engagement relationship between PT Go-Jek and the Go-Jek driver to further ascertain the legal umbrella that can provide optimal protection for both parties, especially the Go-Jek driver.

\section{Materials and Methods}

This research is a legal research, which is using library research data and field research. In legal research, there are times when using statutory approach. To obtain qualitative truths the model is used "analisis-sintesis". To analyse adalah to examine the nature or structure of sth, esp by separating it into its parts, in order to understand or explain it: Analyse the 
sample and identify it. By analysing the parts of the sentence we learn more about English grammar. We must try to analyse the cause of the strike.

This research is a legal research looking from various perspectives[8]. Law is seen as a space for the process of scientific study in order to seek truth. The use of relevant legal research wants to understand the law more thoroughly. In performing implementation analysis, using the method of regulatory impact assessment [9]. The need for RIA (Regulatory Impact Assessment ) use arises from the fact that regulation generally has many impacts[10]. It is as difficult to predict without detailed study and consultation with affected parties. The economic approach to regulatory issues also emphasizes the high risk that regulatory costs can outweigh benefits.

\section{Results and Discussions}

In this discussion section, two main things will be focused on the existence of this article. These two things are first, Accountability of PT. Gojek Indonesia through a partnership agreement with gojek online driver, and secondly, the principles, objectives and partnership pattern as a way of meeting the standards for using transportation.

\subsection{Accountability of PT. Gojek Indonesia Through a Partnership Agreement with Gojek Online Driver}

Partnership seen from an etimological perspective is adapted from the word partnership, and comes from the root of the partner. Partners can be translated pairs, soul mates, allies, or campaigners. The meaning of partnership which translates into partnership or partnership. Starting from here the partnership can be interpreted as a form of communion between two or more parties that form a cooperative relationship on the basis of agreement and a sense of mutual need in order to increase capacity and capability in a particular business field, or a specific goal, so that it can obtain good results.

According to the Big Indonesian Dictionary, the meaning of the word partner is friend, co-worker, colleague. While the partnership means about the relationship or cooperation as partners. Hafsah explained that the meaning of partnership is a business strategy carried out by two or more parties within a certain period of time to gain mutual benefit with the principle of mutual need and mutual nurturing. Because it is a business strategy, the success of the partnership is largely determined by the compliance between those who partner in running business ethics. This is in accordance with the opinion of Ian Linton who said that the Partnership is a way of doing business where suppliers and customers trade with each other to achieve joint business goals.

According to Henri Septanto, economic development with a partnership pattern can be considered as the most profitable business (maximum social benefit), especially in terms of achieving long-term development goals[11]. This is based on the realization of the ideals of a partnership pattern to implement a system of mutual economic cooperation between strong partners in terms of capital, market, and technological capabilities with inexperienced weak class farmers. The aim is to increase business productivity and welfare on the basis of mutual interests.

The essence of partnership lies in joint contributions, both in the form of labor and objects (property) or both for the purpose of economic activities[12]. Control of activities is carried out together where the distribution of profits and losses is distributed between two parties that are partnering:

a. "Partnership or Alliance" is an association consisting of two people or businesses who share a company with the aim of making a profit. 
b. Partnership is an alliance of two or more people as joint owners who run a business seeking profit.

c. A partnership is a company with a number of owners of money enjoying the benefits of the company and each of them bear an unlimited liability for company debts.

Law Number 20 of 2008 concerning Micro, Small and Medium Enterprises Article 1 paragraph 13 states that what is meant by partnerships is cooperation in business relations, both directly and indirectly, on the basis of the principle of mutual need, trust, strengthening, and benefit involving actors Micro, Small and Medium Enterprises with Large Businesses.

All of the definitions above, apparently there is no one definition that provides a complete definition of partnership. This is because the scholars have different focus points in providing understanding about partnerships. But with the difference of opinion among these scholars, it will complement each other's opinions with one another, and if combined it will produce a more perfect definition, that partnership is a business collaboration which is a business strategy between two or more parties with the principle of mutual need, mutual magnification and mutual benefit. The cooperation relationship implied the existence of a coaching and development, this can be seen because basically each party must have weaknesses and strengths, precisely with the weaknesses and strengths of each party will complement each other in the sense that one party will fill in the way of coaching against other weaknesses and vice versa.

\subsection{Principles, Objectives, and Partnership Pattern as a Way of Fulfilling the Standards for The Use of Transportation}

The Court is renewable. The Partnership has principles in its implementation. Roumboutsos[13]formulated three important principles in partnership, namely:

a. Equality or balance (equity). The approach is not top down or bottom up, it is not only based on power, but a relationship of mutual respect, mutual respect and trust. To avoid antagonism, it is necessary to build mutual trust. Equality includes the existence of rewards, obligations, and ties.

b. Fulfillment of Standards for the Use of Transparency Transportation. Transparency is needed to avoid mutual suspicion between partners. Includes transparency in information management and transparency in financial management.

c. Mutual benefits: A partnership must bring benefits to all parties involved.

Basically, the purpose and objectives of the partnership are "win-win solution partnerships". Awareness and mutual benefit here does not mean that participants in the partnership must have the same abilities and strengths, but what is more important is the existence of equal bargaining positions based on their respective roles. Based on cultural approaches, partnerships aim to enable business partners to adopt new values in business such as expanding horizons, initiatives, creativity, taking risks, work ethics, capable of managerial aspects, working on the basis of planning, and looking forward. In ideal conditions, the objectives to be achieved in implementing the partnership more concretely are:
a. Increase small business and community income;
b. Increase added value for partnership actors;
c. Enhancing and empowering communities and small businesses;
d. Increase rural, regional and national economic growth;
e. Expanding employment;
f. Improve national economic resilience. 
According to Law no. 20 of 2008 concerning Micro Business, Small and Medium Enterprises Article 11 states that the objectives of the partnership program are:

a. Realizing partnerships between Micro, Small and Medium Enterprises;

b. Realizing partnerships between Micro, Small, Medium Enterprises and Large Enterprises;

c. Encouraging mutually beneficial relationships in the implementation of business transactions between Micro, Small and Medium Enterprises;

d. Encouraging mutually beneficial relationships in the implementation of business transactions between Micro, Small and Medium Enterprises and Large Enterprises;

e. Develop cooperation to improve the bargaining position of Micro, Small and Medium Enterprises;

f. Encourage the formation of a market structure that guarantees the growth of fair business competition and protects consumers; and

g. Prevent market domination and market concentration by certain individuals or groups that are detrimental to Micro, Small and Medium Enterprises.

In the process of implementation, the partnerships that are run are not always ideal because in the implementation the partnerships carried out are based on the interests of the partners. The partnership between companies and the government and community can lead to three patterns, including:

a. Counter-productive partnership patterns

This pattern will occur if the company is still based on a conventional pattern that only prioritizes the interests of shareholders, namely to pursue maximum profit. The focus of the company's attention is more on how the company can make the most profit, while the relationship with the government and the community or the community is just a mere sweetener. The company runs its own target, the government also does not take care, while the community does not have any access to the company. This relationship only benefits a few people, such as government officials or thugs in the community. Usually, the costs incurred by the company are only used to maintain certain people. This is understood, that for companies that are important is security in the short term.

b. Semiproductive Partnership Pattern

In this scenario the government and community or community are considered as objects and problems outside the company. The company does not know the government programs, the government also does not provide a conducive climate to the business world and the community is passive. This partnership pattern still refers to the shortterm interests and does not or does not give rise to sense of belonging on the community side and low benefits on the side of the government. Cooperation emphasizes charity or public relations aspects, where the government and community or society are still considered as objects. In other words, partnerships are still not strategic and still prioritize the self-interest of the company, not the common interest (commont interest) between the company and its partners.

c. Productive Partnership Pattern

This partnership pattern places partners as subjects and in the commont interest paradigm. The principle of mutualism symbiosis is very thick in this pattern. The company has high social and environmental concerns, the government provides a conducive climate for the business world and the community provides positive support to the company. Even partners can be involved in the relationship pattern of resourced based partnerships, where partners are given the opportunity to be part of shareholders. For example, partners obtain shares through the stock ownership program. 


\section{Conclusion}

The results show that PT Gojek Indonesia can be held accountable and liable related to legal relations through a partnership agreement with online Gojek drivers. Accountability and accountability are based on the legal relationship between the two parties in order to share responsiveness if there is a risk of accidents or damage to the environment caused by online ojek activities. The share responsiveness has a positive impact on maintaining vehicle facilitation indirectly, through maintenance of motorized vehicles on a regular basis and through the replacement of vehicles when the vehicle has exceeded the age of 10 years borne by PT Gojek Indonesia Driver.

\section{References}

1. S. Gössling. Int. J. Sustain. Transp 12, 3 (2018).

2. F. D. Amajida. Informasi 46, 1 (2016).

3. D. Banister and D. Stead. Transp. Rev 24, 5 (2004).

4. R. M. Medeiros, F. Duarte, F. Achmad, and A. Jalali. Transp. Plan. Technol 41 (2018).

5. M. Azhar, S. Suhartoyo, L. T. Alw, P. Suharso, and V. E. Herawati. E3S Web Conf. SCiFiMaS 47 (2018).

6. M. Azhar, S. Suhartoyo, P. Suharso, V. E. Herawati, and N. Trihastuti. E3S Web Conf. SCiFiMaS 47 (2018).

7. D. T. S. Tarigan, I. W. Wiryawan, and I. N. Mudana, Analisis perjanjian kerjasama kemitraan pt. go-jek dengan driver berdasarkan undang-undang no.13 tahun 2003 tentang ketenagakerjaan. (Denpasar, Fakultas Hukum UDAYANA)

8. G. Samuel, Comparative law ant its methodology in research methods in law (Routledge, 2013)

9. C. H. Kirkpatrick and D. Parker, Regulatory Impact Assessment: Towards Better Regulation (Cheltenham, Edward Elgar, 2007)

10. A. Grifflths, Using eihnography as a tool in legal research: an anthropological perspective in theory and method in socio-legal research (Portland, Hart Publishing, 2005)

11. H. Septanto. ICT J 3, 1 (2016).

12. A. Saz-carranza and F. Longo. Public Manag. Rev 14, 3 (2012).

13. A. Roumboutsos. Transp. Rev. A Transnatl 35, 2 (2015). 